Short Communication

\title{
Preparation of ZnO Nanosheets-Nanorods Hierarchically Structured Films and Application in Quantum Dots Sensitized Solar Cells
}

Zeng Chen, Shengjun Li ${ }^{*}$, Chaochao Wei, Chunli Diao, Qingqing Pei, Junhao Cai, Weifeng Zhang

Henan Key Laboratory of Photovoltaic Materials, Henan University, Kaifeng 475001, China

*E-mail: lishengjun1011@126.com

doi: $10.20964 / 2017.08 .54$

Received: 10 April 2017 / Accepted: 11 June 2017 / Published: 12 July 2017

$\mathrm{ZnO}$ nanosheets were electrodeposited on transparent conductive glass substrates. Thereafter, $\mathrm{ZnO}$ nanorods were grown vertically on the nanosheets by hydrothermal method to prepare the nanosheetsnanorods hierarchically structured $\mathrm{ZnO}$ films. The influence factors, such as the concentration of precursor solution and the hydrothermal reaction time, were studied. The obtained nanosheetsnanorods hierarchically structured $\mathrm{ZnO}$ films were co-sensitized with $\mathrm{CdS}$ and $\mathrm{CdSe}$ quantum dots and applied as the photoanodes of dye-sensitized solar cells. A photoelectric conversion efficiency of $2.50 \%$ was obtained after the coating of $\mathrm{TiO}_{2}$ on the $\mathrm{ZnO}$ nanosheets-nanorods.

Keywords: $\mathrm{ZnO}$, nanosheets, nanorods, hierarchically structured films, dye-sensitized solar cells

\section{FULL TEXT}

(C) 2017 The Authors. Published by ESG (www.electrochemsci.org). This article is an open access article distributed under the terms and conditions of the Creative Commons Attribution license (http://creativecommons.org/licenses/by/4.0/). 